\title{
Effects of sevoflurane exposure on apoptosis and cell cycle of peripheral blood lymphocytes, and immunologic function
}

Zhimin $\mathrm{Ji}^{1}$, Wanjun $\mathrm{Wu}^{2}$, Fan Zhou ${ }^{3}$, Junfang Hu${ }^{4}$, Qiuping $\mathrm{Xu}^{1}$, Weibin Yang ${ }^{3}$, Xueyong Peng ${ }^{1}$, Xinguo Wang ${ }^{5}$, Cheng Zhang ${ }^{6}$ and Li Li ${ }^{* *}$

\begin{abstract}
Background: Waste anesthetic gases (WAGs) leaked from new-type halogenated inhalational anesthetics such as sevoflurane have been were reported to pose a risk for the health of operating room personnel. The effects of WAGs on peripheral blood lymphocytes, however, remain yet controversial. The present study was undertaken to examine the effects of occupational sevoflurane exposure on the peripheral blood lymphocytes of medical personnel who work in the operating room.

Methods: A cohort of 56 medical residents were divided into exposed group $(n=28)$ and control group (nonexposed group) ( $n=28$ ). Gas chromatography was used to measure the concentration of sevoflurane in the medical resident's breathing zone during surgeries under inhalation anesthesia in the exposure group. The gas collection lasted an hour. Peripheral blood lymphocytes were isolated from venous blood, and then apoptosis and cell cycle were analyzed by flow cytometry. EDTA-anticoagulated whole blood was harvested to analyze the lymphocyte subsets by flow cytometry. Immunoglobulins (IgA, IgM, IgG) were quantified by immunoturbidimetry.

Results: The average concentration of sevoflurane in the exposed group was 1.03 ppm with a range from 0.03 ppm to $2.24 \mathrm{ppm}$. No significant effects were found on the apoptosis rates or cell cycles of peripheral blood lymphocytes in the exposed group relative to the control group $(P>0.05)$. Similarly, there were no significant differences in the lymphocyte subsets or the levels of immunoglobulins ( $\lg \mathrm{A}$, $\lg \mathrm{M}, \lg \mathrm{G})$ between the two groups $(P>0.05)$.

Conclusions: Occupational exposure to low-level sevoflurane has no significant effect on the peripheral blood lymphocytes of operating room staff, but this conclusion needs to be confirmed by multicenter and long-term follow-up studies with large samples.
\end{abstract}

Trial registration number and date of registration: ChiCTR2000040772, December 9, 2020 (Retrospective registration).

Keywords: Sevoflurane, Apoptosis, Cell cycle, Peripheral blood lymphocytes, Immunologic function

\footnotetext{
*Correspondence: lili1001@wust.edu.cn

Zhimin Ji first author.

${ }^{7}$ Department of Pathology, Puren Hospital Affiliated to Wuhan University of Science and Technology, Wuhan, China

Full list of author information is available at the end of the article
} 
Table 1 The characteristics of the study populations

\begin{tabular}{llll}
\hline & $\begin{array}{l}\text { Control group } \\
(\mathbf{n = 2 8})\end{array}$ & $\begin{array}{l}\text { Exposed group } \\
(\mathbf{n = 2 8 )}\end{array}$ & $\boldsymbol{P}$ value \\
\hline Age(years) & & & $0.18^{*}$ \\
Mean \pm SD & $34.04 \pm 6.03$ & $32.14 \pm 4.34$ & \\
Range & $25-48$ & $27-46$ & \\
Sex (male/female) & & $0.59^{\#}$ \\
$\quad$ male & 17 & 15 & \\
Female $\quad 11$ & 13 & \\
Duration of exposure(years) & & \\
\multicolumn{2}{l}{ Range } & $2-20$ &
\end{tabular}

*Independent sample t test

${ }^{\#}$ Chi-square test

\section{Background}

With the advantage of low solubility in blood and high controllability, inhalation anesthetics are widely used in the operating room (OR), dental clinic, delivery room, MRI room and intensive care unit [1, 2]. Despite many improvements in the anesthesia equipment and the production of safer anesthetic agents during the past decades, inhalation anesthetics, including halothane, isoflurane, sevoflurane, desflurane, and nitrous oxide $\left(\mathrm{N}_{2} \mathrm{O}\right)$, inevitably cause waste anesthetic gases (WAGs) in the workplace $[3,4]$. Furthermore, chronic occupational exposure to the volatile anaesthetics has been reported to negatively impact the health of hospital personnel since these agents were introduced into clinical use in the $1990 \mathrm{~s}[1,5,6]$. Some researchers believe, however, that there are no statistically sound studies identifying the concentrations of anesthetic gases that would exert harmful effects [7-9]. Moreover, the effects of the inhalational anesthetics on

Table 2 Comparison of apoptosis rate and cell cycle between control group and exposed group

\begin{tabular}{lllllll}
\hline Cell cycle & group & N & mean & SD & t & $\begin{array}{l}\boldsymbol{P} \\
\text { value }\end{array}$ \\
\hline G1\% of total cell number & control & 28 & 84.79 & 11.36 & 1.11 & 0.27 \\
& exposed & 28 & 81.49 & 11.0 & & \\
Mean DNA content of G1 & control & 28 & 48.54 & 2.46 & 1.62 & 0.11 \\
phase & exposed & 28 & 47.50 & 2.33 & & \\
G2\% of total cell number & control & 28 & 7.02 & 3.17 & 0.06 & 0.95 \\
& exposed & 28 & 6.98 & 2.56 & & \\
Mean DNA content of G2 & control & 28 & 97.41 & 5.98 & 1.83 & 0.07 \\
phase & exposed & 28 & 94.60 & 5.47 & & \\
S\% of total cell number & control & 28 & 6.89 & 9.92 & -0.79 & 0.44 \\
& exposed & 28 & 9.07 & 10.83 & & \\
apoptosis rate & control & 28 & 6.26 & 4.87 & -0.542 & 0.59 \\
& exposed & 28 & 7.03 & 5.73 & & \\
\hline
\end{tabular}

lymphocytes apoptosis remain controversial. Matsuoka et al. found that sevoflurane induced apoptosis in peripheral lymphocytes in dose-dependent and time-dependent manners in vitro [10]. Loop et al. also documented that sevoflurane induced T cells apoptosis in vitro [11]. On the contrary, Aun et al. failed to reveal significant differences in the percentages of viable and early apoptotic cells detected by flow cytometry between medical residents with and without brief occupational exposure [12]. Thus, the present cohort study was undertaken to ascertain whether
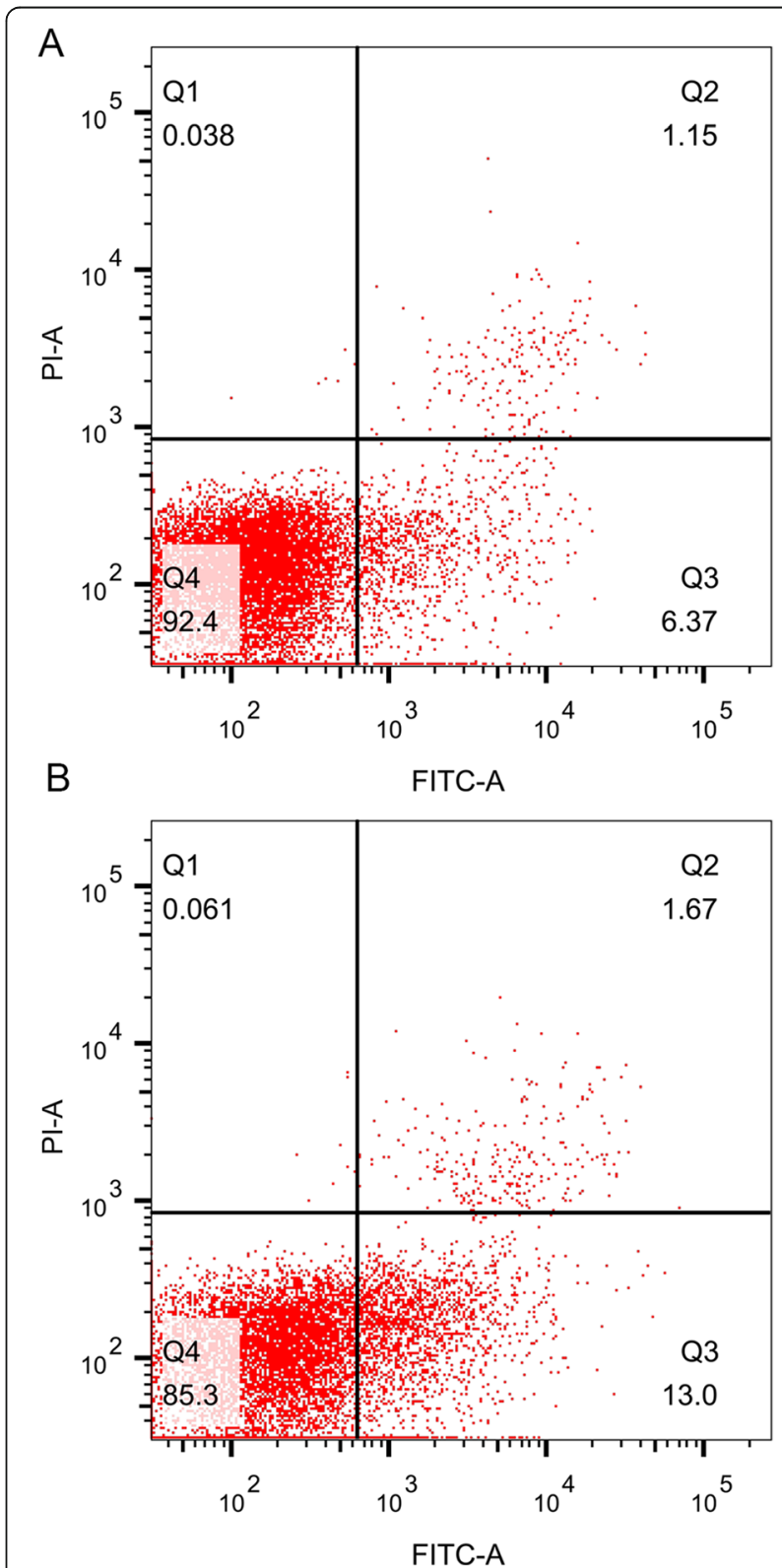

Fig. 1 Apoptosis of peripheral blood lymphocyte analyzed by flow cytometry. $\mathbf{a}$ is representative picture of control group. $\mathbf{b}$ is representative picture of exposed group 

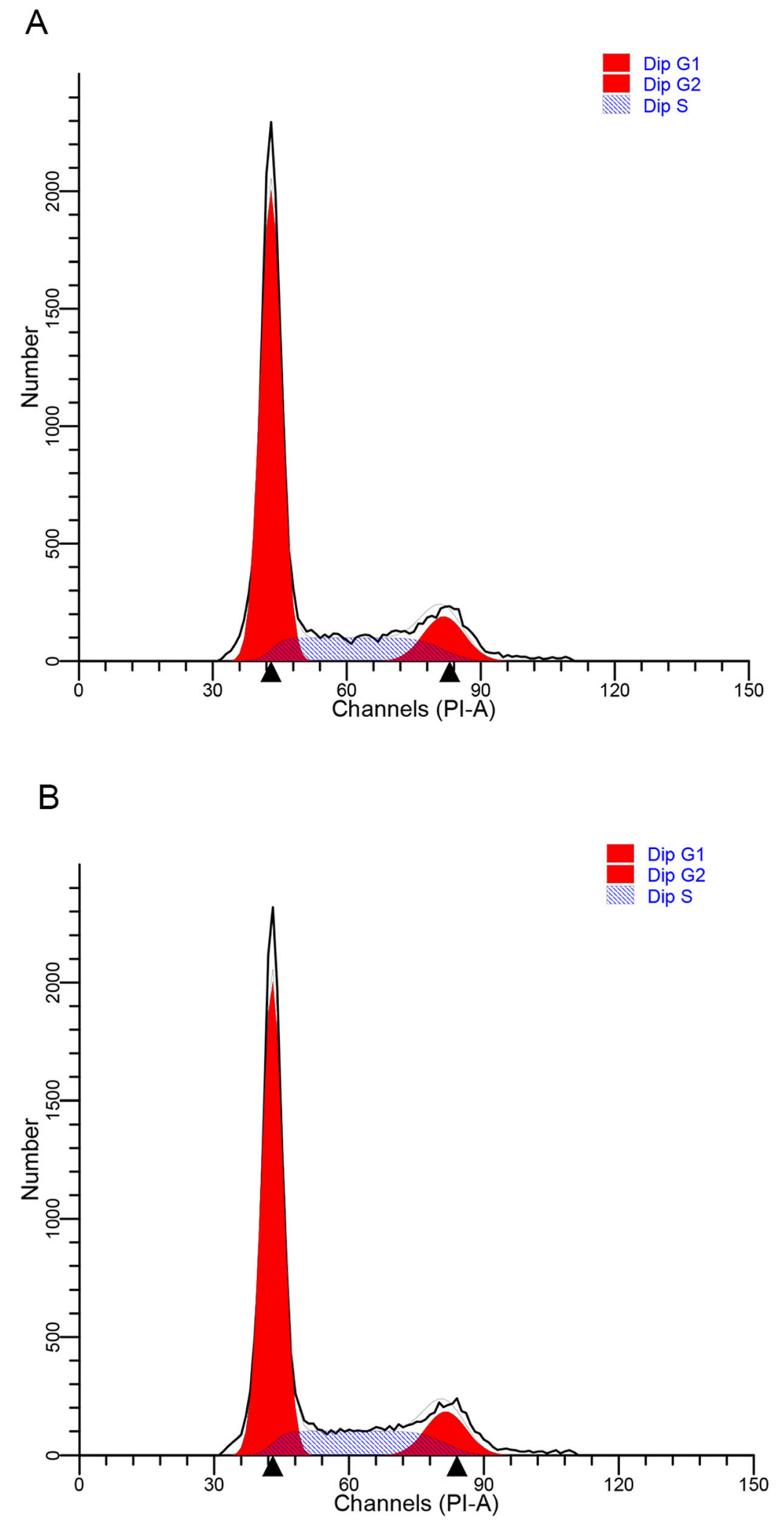

Fig. 2 Cell cycle of peripheral blood lymphocyte analyzed by flow cytometry. $\mathbf{a}$ is representative picture of control group. $\mathbf{b}$ is representative picture of exposed group 
occupational exposure to sevoflurane has harmful effects on the peripheral blood lymphocytes of medical personnel exposed to inhalational anesthetics in vivo.

\section{Methods}

Study design and occupational exposure

This study was approved by the Human Medical Research Ethics Review Board, Puren Hospital (prll2018001) prior to its initiation. All subjects who participated in this study provided written informed consent. This study was conducted in accordance with the stringent ethical requirements for research on human subjects. All participants answered a standardized and detailed questionnaire that included demographic data, medical history, lifestyle and anesthetic exposure before each blood sample was collected. To avoid the effects of possible confounding factors, subjects were excluded from the study if they were pregnant women, had any chronic infectious or inflammatory disease, were using illicit substances, medications, vitamins, and/or antioxidant supplements, had recently been exposed to radiation (within 6 month), or had medical or family history of blood diseases. The exposed group consisted of 28 anesthetists who were mainly exposed to sevoflurane for at least 24 months. The control group comprised 28 residents from internal medicine who were not exposed to WAGs or other pollutants. The exposed group was age- and sex-matched with the unexposed group. The biological sampling was performed from 2019 to 2020.

\section{Measurement of WAGs in the breathing zone of medical residents during surgeries}

The Puren hospital maintains 13 ORs with an average area of 25 square meters each. The ORs do not have scavenging systems, but instead maintain vertical
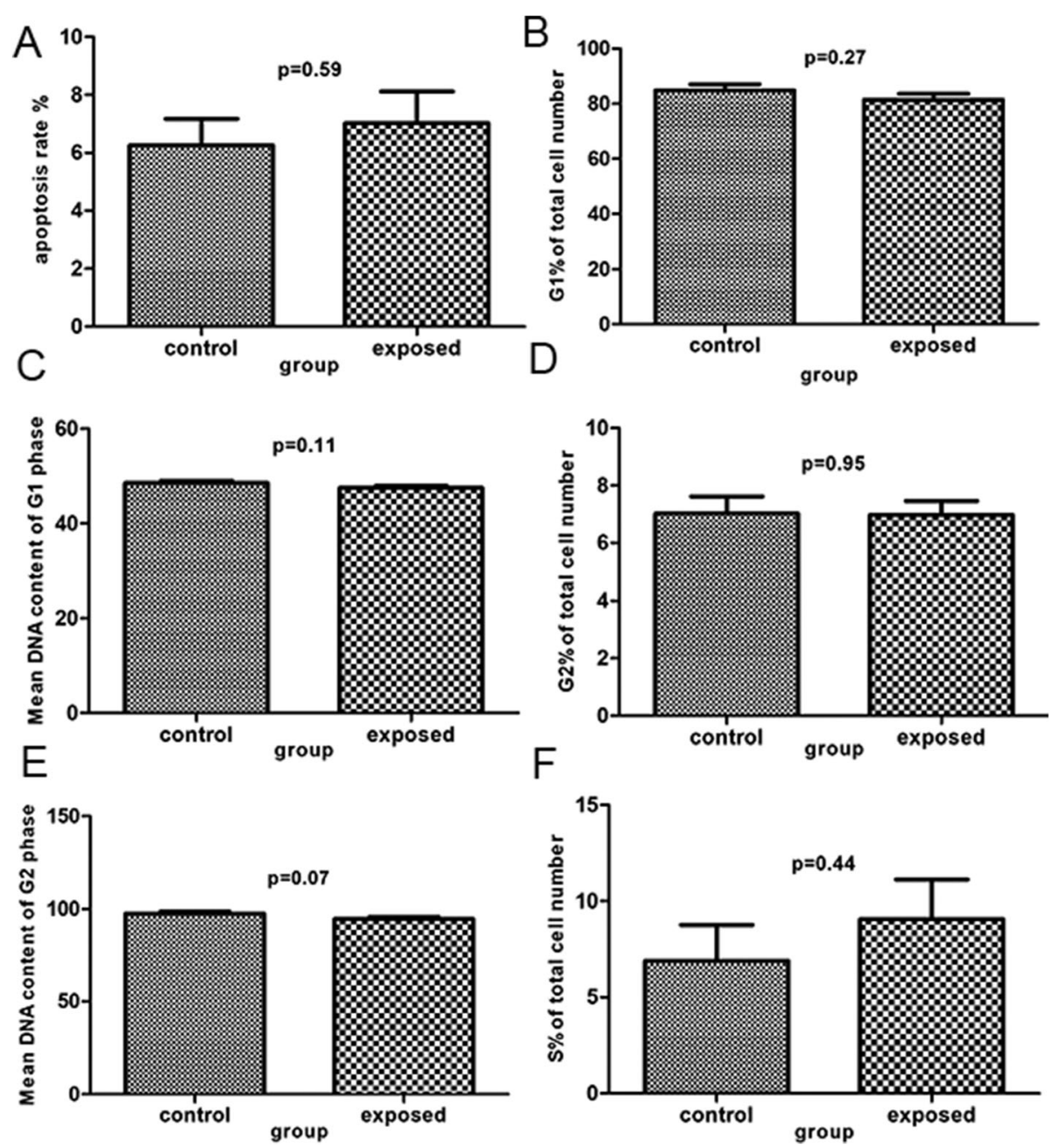

Fig. 3 Cartogram of apoptosis rate and cell cycle. $\mathbf{a}$ is comparation of apoptosis rate of control group and exposed group. $\mathbf{b}$, $\mathbf{d}$ and $\mathbf{f}$ represent percentage of G1 phase, G2 phase and S phase of cell cycle. $\mathbf{c}$ and $\mathbf{e}$ display mean DNA content of G1 phase and G2 phase respectively 
laminar flow conditions. All the medical residents from the exposed group worked in the 13 ORs in the hospital. All the WAGs were collected from the breathing zone of medical residents during the conduct of surgical inhalation anesthesia in all the ORs. The gas collection lasted an hour. The measurements were performed by using a GilAir-5 sampler (Sensidyne, USA) and Agilent
7890BGas Chromatograph System (Agilent Technologies, USA) according to the instruction of the manufacturer. The average of the gas concentration of sevoflurane was calculated and shown in ppm. Measurement requirement was in accordance with procedures approved by the National Institute for Occupational Safety and Health (NIOSH) [13].

Table 3 Comparison subpopulation of Lymphocyte between control group and exposed group

\begin{tabular}{|c|c|c|c|c|c|c|}
\hline subpopulation of lymphocyte & group & $\mathrm{N}$ & mean & SD & $\mathrm{t}$ & $P$ value \\
\hline \multirow[t]{2}{*}{ T cells $\%$ of lymphocyte } & control & 28 & 64.18 & 8.76 & 1.81 & 0.08 \\
\hline & exposed & 28 & 59.91 & 8.86 & & \\
\hline \multirow[t]{2}{*}{ Helper T cells\% of T cells } & control & 28 & 40.83 & 8.75 & 0.72 & 0.47 \\
\hline & exposed & 28 & 39.17 & 8.43 & & \\
\hline \multirow[t]{2}{*}{ Killer T cells\% of T cells } & control & 28 & 49.29 & 8.93 & -0.67 & 0.50 \\
\hline & exposed & 28 & 50.92 & 9.18 & & \\
\hline \multirow[t]{2}{*}{ Th to Tc ratio } & control & 28 & 0.89 & 0.37 & 0.68 & 0.50 \\
\hline & exposed & 28 & 0.82 & 0.33 & & \\
\hline \multirow[t]{2}{*}{ ImmatureCD4+T cells\% of CD4+T cells } & control & 28 & 92.53 & 4.06 & 0.62 & 0.54 \\
\hline & exposed & 28 & 91.70 & 5.96 & & \\
\hline \multirow[t]{2}{*}{ Mature $\mathrm{CD} 4+\mathrm{T}$ cells\% of $\mathrm{CD} 4+\mathrm{T}$ cells } & control & 28 & 7.47 & 4.06 & -0.62 & 0.54 \\
\hline & exposed & 28 & 8.32 & 5.96 & & \\
\hline \multirow[t]{2}{*}{ Immature/mature CD4+T cells } & control & 28 & 17.41 & 11.08 & -0.67 & 0.51 \\
\hline & exposed & 28 & 20.03 & 17.43 & & \\
\hline \multirow[t]{2}{*}{ Immature $\mathrm{CD} 8+\mathrm{T}$ cells $\%$ of $\mathrm{CD} 8+\mathrm{T}$ cells } & control & 28 & 63.64 & 9.49 & 1.16 & 0.25 \\
\hline & exposed & 28 & 60.69 & 9.64 & & \\
\hline \multirow[t]{2}{*}{ Mature $\mathrm{CD} 8+\mathrm{T}$ cells\% of $\mathrm{CD} 8+\mathrm{T}$ cells } & control & 28 & 36.35 & 9.49 & -1.16 & 0.25 \\
\hline & exposed & 28 & 39.31 & 9.64 & & \\
\hline \multirow[t]{2}{*}{ Immature/mature CD8+T cells } & control & 28 & 1.92 & 0.70 & 1.22 & 0.23 \\
\hline & exposed & 28 & 1.70 & 0.67 & & \\
\hline \multirow[t]{2}{*}{ Regulatory T cells\% of CD4 T cells } & control & 28 & 2.96 & 0.58 & 0.21 & 0.83 \\
\hline & exposed & 28 & 2.93 & 0.63 & & \\
\hline \multirow[t]{2}{*}{ B cells\% of lymphocyte } & control & 28 & 12.68 & 3.42 & -1.59 & 0.12 \\
\hline & exposed & 28 & 14.36 & 4.41 & & \\
\hline \multirow[t]{2}{*}{ NK cells\% of lymphocyte } & control & 28 & 16.19 & 7.25 & -1.52 & 0.14 \\
\hline & exposed & 28 & 18.86 & 5.87 & & \\
\hline \multirow[t]{2}{*}{ Immature NK cells\% of NK cells $\downarrow$} & control & 28 & 10.18 & 7.08 & 0.60 & 0.55 \\
\hline & exposed & 28 & 9.14 & 5.98 & & \\
\hline \multirow[t]{2}{*}{ Mature NK cells\% of NK cells $\downarrow$} & control & 28 & 89.81 & 7.08 & -0.53 & 0.60 \\
\hline & exposed & 28 & 90.74 & 5.92 & & \\
\hline \multirow[t]{2}{*}{ Immature/mature NK cells } & control & 28 & 0.12 & 0.10 & 0.80 & 0.43 \\
\hline & exposed & 28 & 0.10 & 0.08 & & \\
\hline \multirow[t]{2}{*}{ TNK cells\% of lymphocyte } & control & 28 & 11.32 & 4.63 & 0.86 & 0.39 \\
\hline & exposed & 28 & 10.15 & 5.44 & & \\
\hline \multirow[t]{2}{*}{ үઠ T cells\% of T cells } & control & 28 & 7.85 & 4.33 & 0.16 & 0.88 \\
\hline & exposed & 28 & 7.67 & 4.31 & & \\
\hline
\end{tabular}


Peripheral blood lymphocyte preparation

EDTA anticoagulated venous blood samples were collected from median cubital vein of all participants. Peripheral blood lymphocytes were separated within subsequent 10-20 $\mathrm{min}(\mathrm{min})$ with a standard method by centrifugation over lymphocyte separation medium at $400 \times \mathrm{g}$ for 20 min (lymphoprep ${ }^{\text {tw }}$, STEMCELL technologies, Canada). The cells were washed with phosphate-buffered saline (PBS) $(250 \times \mathrm{g}, 10 \mathrm{~min})$. Subsequently, $5 \times 10^{5} / \mathrm{ml}$ peripheral blood mononuclear cells (PBMCs) suspended in the PBS were used in all the experiments.

\section{Assessments of apoptosis}

The percentages of viable (annexin-/propidium iodide [PI]-) or early apoptotic (annexin+/PI-) cells were quantified by using annexin V-fluorescein isothiocyanate (FITC) staining, which was used to detect phosphatidylserine that is externalized in the early phases of apoptosis. Annexin V is an important marker of early apoptosis in which changes in externalized phosphatidylserine levels occur prior to DNA fragmentation [14]. We used the Annexin V-FITC Apoptosis Analysis Kit according to the manufacturer's instructions (Tianjin Sungene Biotech Co., Ltd., China). Mononuclear cells $\left(1 \times 10^{5}\right)$ were labeled, incubated in the dark for $15 \mathrm{~min}$ and immediately sorted by flowcytometry (BD FACS Aria $^{\mathrm{TM}}$ ш, USA). Marked annexin V-FITC staining (green) was analyzed using the FL-1channel, while PI staining (red) was assessed using the FL-2 channel. The data were analyzed by using the FlowJo software on a BD FACS Aria ${ }^{\text {Th }}$ cytometer (BD BioSciences, USA).
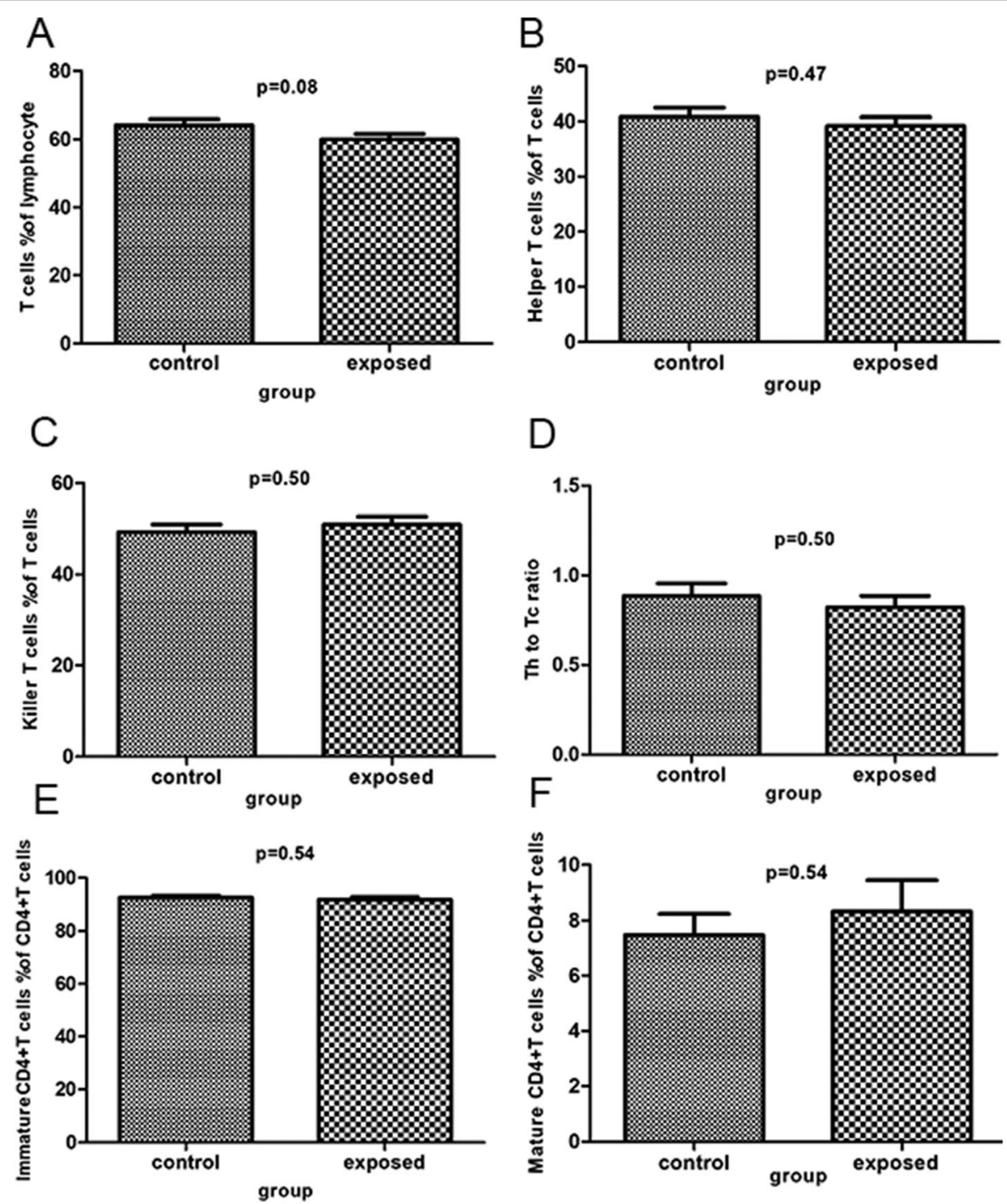

Fig. 4 Analysis of subpopulation of lymphocyte by flow cytometry. a-f reveal various subpopulation of lymphocyte as follows: T cells \% of lymphocyte, Helper T cells \% of lymphocyte, Killer T cells \% of T cells, Th to Tc ratio, ImmatureCD4+T cells \% of CD4+T cells, Mature CD4+T cells $\%$ of CD4+T cells 
Cell cycle analysis

Cell cycle was examined by flow cytometry according to a previous report [15]. Briefly, cells $\left(1 \times 10^{6}\right)$ were harvested and washed with $10 \mathrm{ml}$ PBS by centrifugation for $5 \mathrm{~min}$ at $300 \times \mathrm{g}$, and then re-suspended in $0.5 \mathrm{ml} \mathrm{PBS}$. They were fixed by adding $4.5 \mathrm{ml}$ prechilled $70 \%$ ethanol while vortexing. After incubation for $2 \mathrm{~h}$ at $4{ }^{\circ} \mathrm{C}$, residual ethanol was eliminated by centrifugation for $5 \mathrm{~min}$ at $300 \times \mathrm{g}$. Supernatants were removed and discarded. Cells were washed with $5 \mathrm{ml}$ FACS buffer twice by centrifugation for $5 \mathrm{~min}$ at $200 \times$ g. Cells were stained using $0.5 \mathrm{ml}$ propidium iodide staining solution and kept in dark. Afterwards, they were incubated for $20 \mathrm{~min}$ at room temperature and the fluorescence analyzed using the ModFit LT software on BD FACSCalibur cytometry (BD, BioSciences USA).

\section{Analysis of subpopulations of lymphocyte by flow cytometry} EDTA-anticoagulated whole blood were freshly collected from median cubital vein and processed within $2 \mathrm{~h}$ by tencolor flow cytometry (BD FACSCanto ${ }^{\mathrm{\tau m}}$, USA) to analyze the lymphocyte subsets as previously described [16, 17]. The lymphocyte subsets were identified using the following monoclonal antibodies: anti-CD3-APC-H7, anti-CD8PerCP-cy5.5, anti-CD4-BV605, anti-CD25-PE, anti-CD56BV510, anti-CD19-APC, and anti- $\gamma \delta-B V 421$ from BD Biosciences; anti-CD28-PE-CY7 and anti-CD127-FITC from

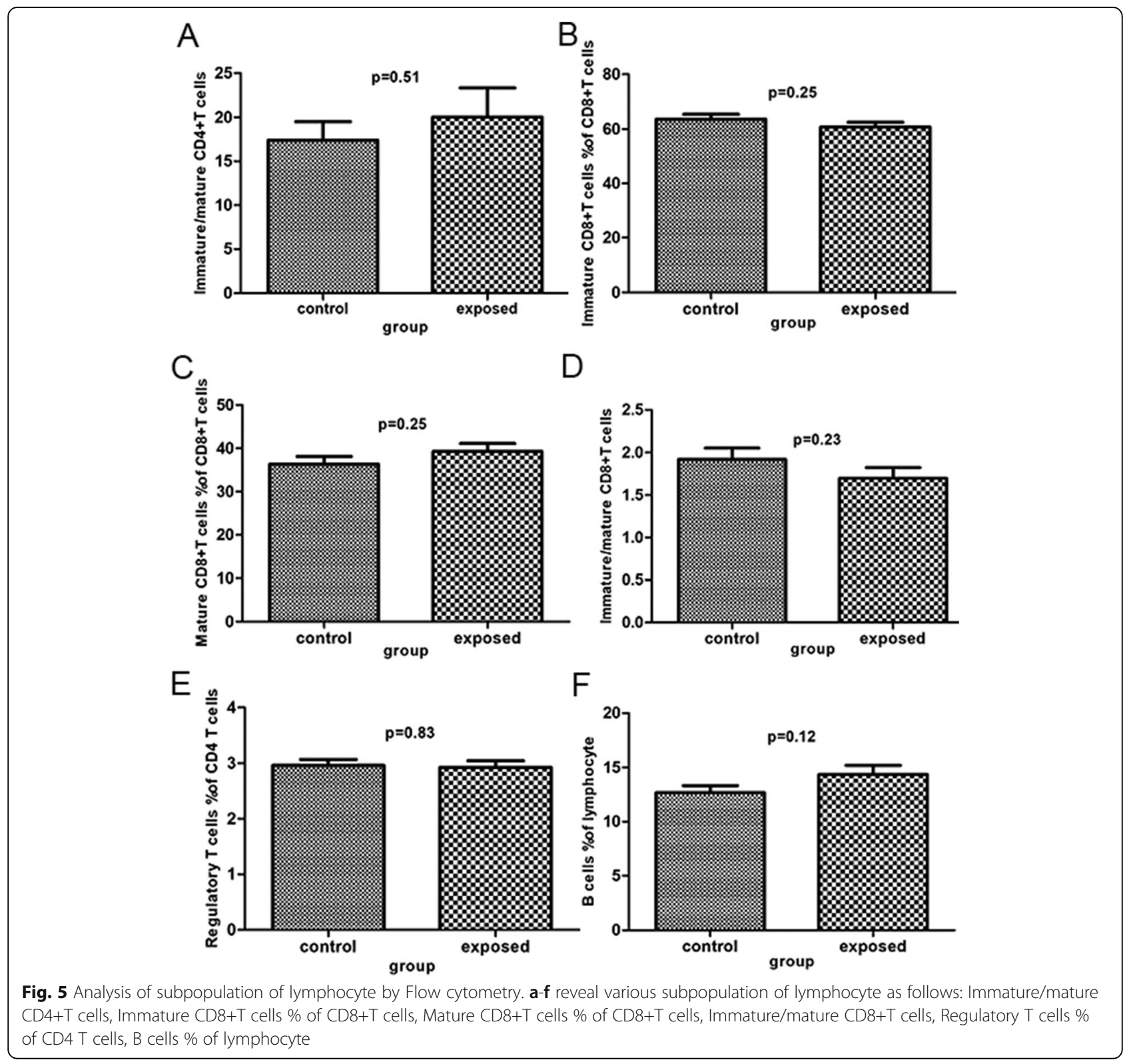


Biolegend. The cell suspension was incubated at room temperature in the dark for $30 \mathrm{~min}$. Red blood cells were removed using $500 \mu \mathrm{l}$ of lysis buffer at room temperature in the dark for $10 \mathrm{~min}$. Finally, the cells were analyzed by using FACS Canto flow cytometry and Flowjo software (BD BioSciences, USA).

\section{Immunoglobulin quantification by immunoturbidimetry}

Blood of the median cubital vein was collected into separate gel coagulant tub and the content of immunoglobulins (IgA, IgG, IgM) in the serum was detected by Immunoturbidimetric Assay according to the instructions of immunoglobulin assay kit (Shanghai Fosun Long
March Medical Science co., LTD) on an automatic biochemical analyzer (beckmancoulterAU5800, USA).

\section{Statistical analysis}

Data were analyzed using an SPSS software version 25. The sample size for this study was calculated based on a pilot study, with a test power of $80 \%$ and level of $5 \%$ of significance (mean expected differences of 7.02 and 7.85 standard deviations between two groups), and was determined to be 52 subjects. By adding a $10 \%$ sample shedding rate, finally, the sample size was 56 . Independent student's $t$-test was used for comparing the mean of quantitative variables, and

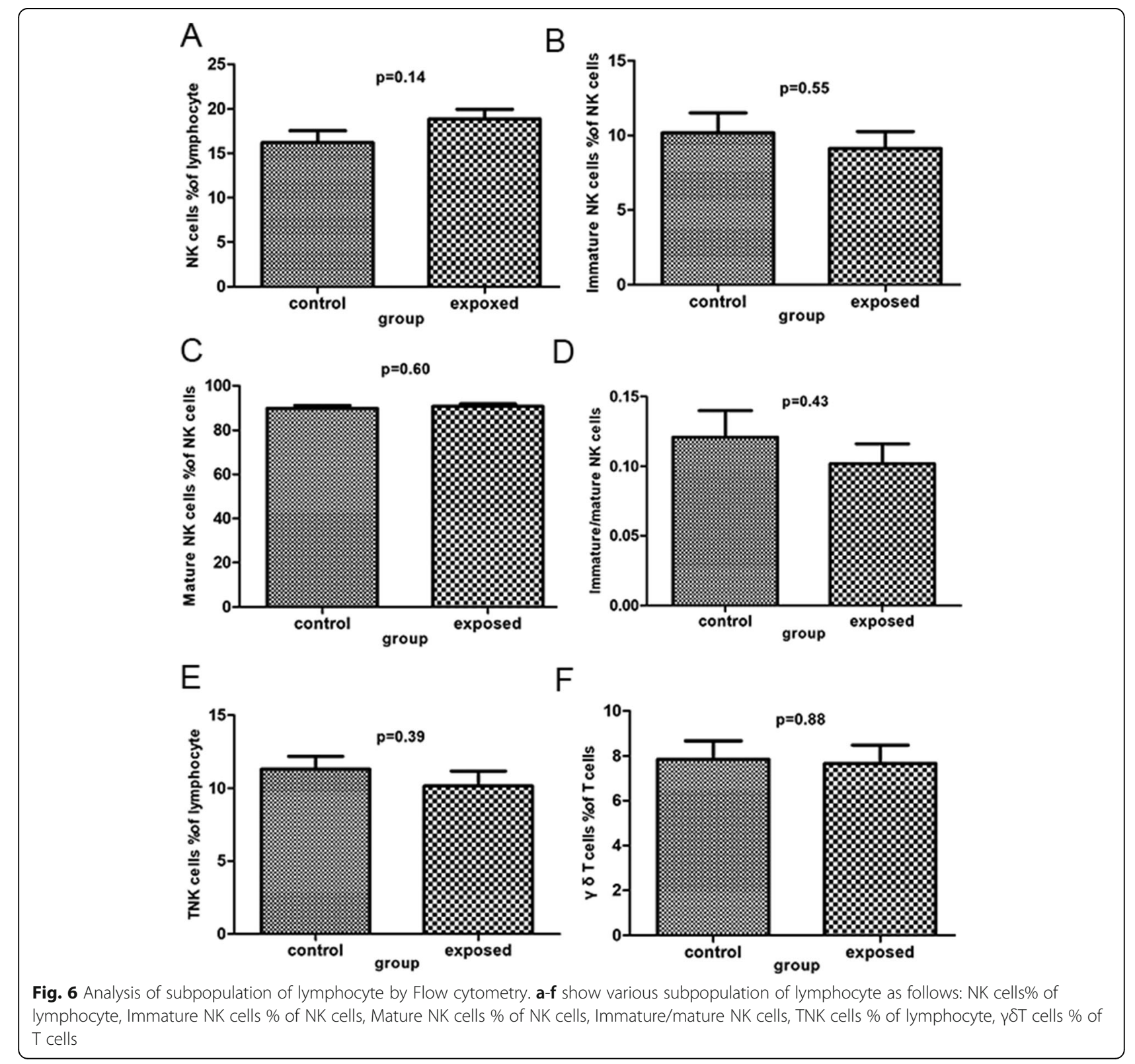


chi-square for comparing the mean of qualitative variables. $P$-values less than 0.05 were considered to be significant.

\section{Results}

Demographic characteristics of the study populations

The demographic characteristics of the exposed and the control groups are shown in Table 1 . No statistically significant differences were noted between the two groups in these variables (age and sex) $(P>0.05)$.

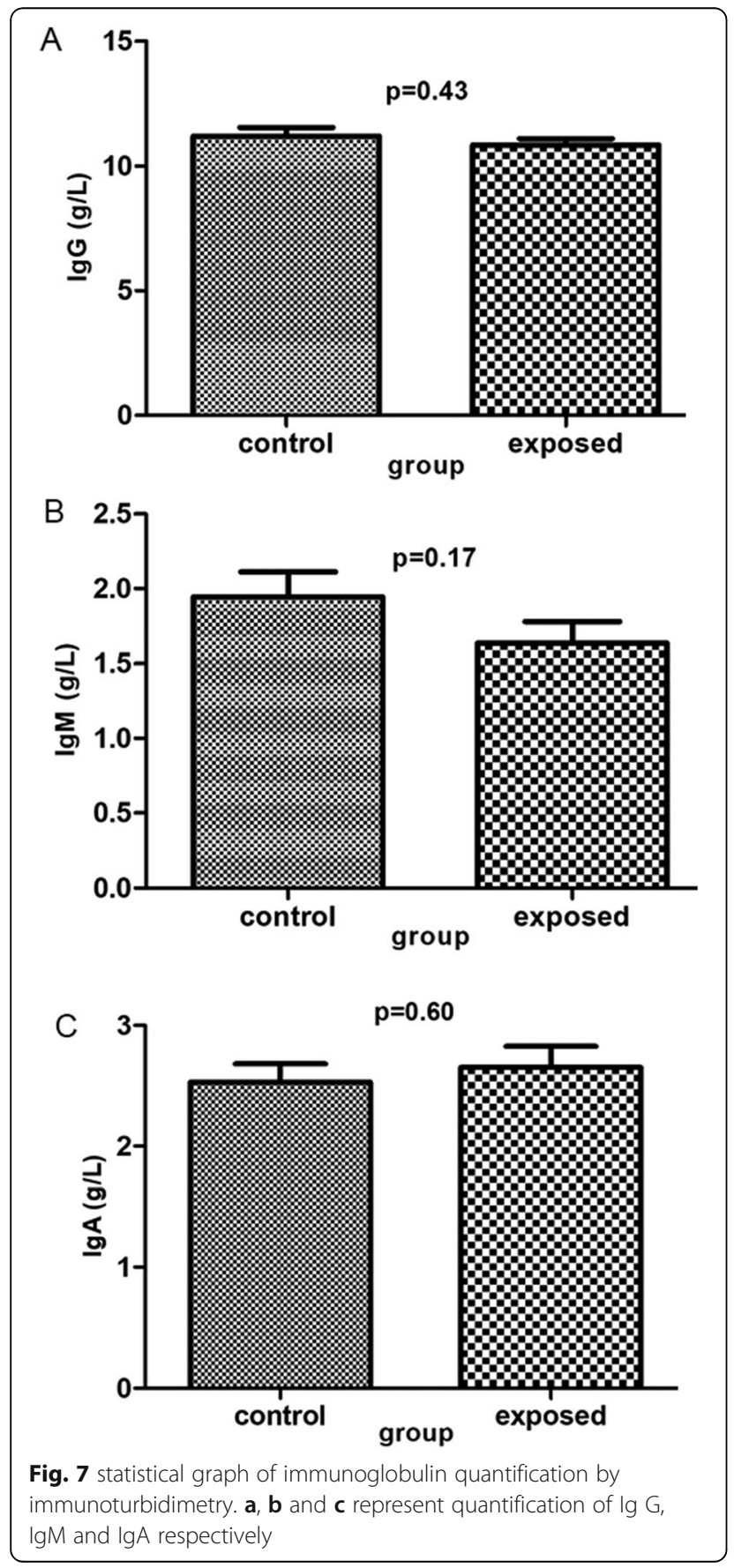

Concentration of sevoflurane in exposed group is lower than the standard of NIOSH

After analyzing the concentration of sevoflurane collected from the breathing zone of all residents in the exposed group, we found that the average concentration of sevoflurane was $1.03 \mathrm{ppm}$ with a range from $0.03 \mathrm{ppm}$ to $2.24 \mathrm{ppm}$. The value was lower than the limit recommended by NIOSH.

\section{Sevoflurane exposure has no significant effect on} apoptosis and cell cycle of peripheral blood lymphocytes As shown in Table 2; Figs. 1, 2 and 3, we found that there were no statistically significant differences in the apoptosis rates or cell cycles of the peripheral blood lymphocytes between control group and exposed group $(P>0.05)$. In addition, sevoflurane exposure had no significant effects on cells at G1 phase, G2 phase or S phase in the exposed group compared with the control group $(P>0.05)$. Although the proportion of S-phase cells and the apoptosis rate were slightly higher in the exposed group than in the control group, the differences were not statistically significant $(P>0.05)$.

\section{Sevoflurane exposure has no significant impacts on subpopulations of lymphocytes}

There were no statistically significant differences in all subpopulations of lymphocytes between the exposed group and the control group $(P>0.05$, Table 3; Figs. 4,5 and 6). Specifically, the percentages of helper $\mathrm{T}$ cells, killer $\mathrm{T}$ cells, $\mathrm{Th}$ to $\mathrm{Tc}$ ratio, immature CD4 + T cells, regulatory T cells, mature NK cells and $\gamma \delta \mathrm{T}$ cells in the exposed group were not significantly different from those in the control group. There was a trend toward slightly lower percentages of mature CD4 + T cells, mature CD8 + T cells, NK cells, immature/mature CD4 $+\mathrm{T}$ cells and $\mathrm{B}$ cells in the control group compared to the exposed group, but the differences were not statistically significant. In addition, the percentages of $\mathrm{T}$ cells, immature $\mathrm{CD} 8+\mathrm{T}$ cells, immature/mature CD8 + T cells, immature NK cells, immature/mature NK cells and TNK cells tended to

Table 4 Comparison of Immunoglobulin quantification between control group and exposure group

\begin{tabular}{lllllll}
\hline $\begin{array}{l}\text { Immunoglobulin } \\
\text { quantification(g/l) }\end{array}$ & group & $\mathbf{N}$ & mean & SD & $\mathbf{t}$ & $\begin{array}{l}\boldsymbol{P} \\
\text { value }\end{array}$ \\
\hline $\operatorname{lgG}$ & & & & & & \\
& control & 28 & 11.20 & 1.85 & 0.80 & 0.43 \\
$\operatorname{lgM}$ & exposed & 28 & 10.85 & 1.37 & & \\
& control & 28 & 1.94 & 0.88 & 1.41 & 0.17 \\
$\operatorname{lgA}$ & exposed & 28 & 1.64 & 0.75 & & \\
& control & 28 & 2.53 & 0.80 & -0.53 & 0.60 \\
& exposed & 28 & 2.65 & 0.92 & & \\
\hline
\end{tabular}


increase in the control group relative to the exposed group $(P>0.05)$.

\section{Sevoflurane exposure has no influence on the levels of immunoglobulins}

Immunoglobulins, including $\operatorname{IgA} \operatorname{IgM}$, and $\operatorname{IgG}$, were not significantly different in the exposed group from those in the control group $(P>0.05$ Table 4; Fig. 7).

\section{Discussion}

Our study demonstrated that the concentration of sevoflurane in the breathing zone of medical residents working in the OR was lower than the standard of $\mathrm{NIOSH}$. In addition, chronic sevoflurane exposure had no significant effects on the apoptosis rates or cell cycles of peripheral blood lymphocytes in exposed medical staff. Finally, there were no significant differences in the subpopulations of lymphocytes or the levels of immunoglobulins (IgA, IgM, IgG) between the exposed group and controls.

Consistently, a recent study by Aun et al. did not found significant differences in the percentages of viable or early apoptotic cells detected by flow cytometry among medical residents with brief occupational exposure in vivo. Their study was performed before the medical residency program (no exposure; the physicians served as their own controls) and again after $1 / 2$ year and 1 year of exposure [12]. Though previous studies found that sevoflurane induced apoptosis in peripheral lymphocytes in vitro $[10,11]$, we believe that the findings from experiments in vitro cannot be directly applied to actual conditions in vivo. The reason for this inconsistency may be speculated as follows: (1) such low concentration of sevoflurane is not enough to cause remarkable influences on peripheral blood lymphocytes. (2) Some regulatory mechanisms in vivo may correct the effects of sevoflurane exposure on peripheral blood lymphocytes. (3) Regeneration of peripheral blood lymphocytes alleviates the degree of cell injury from sevoflurane. Indeed, based on prior studies, there is not sound evidence that trace concentrations of anesthetic gases exert harmful effects [7]. Only high concentration levels of anesthetic agents and long-time exposure have been proven to result in significant histotoxicity [7]. Byhahn believe, under modern air conditioning, personnel's occupational exposure is low, and inhalational anesthesia is safe from the standpoint of modern workplace laws and health care regulations [18]. Our study further supports the conclusions mentioned above by analyzing the actual effects of sevoflurane on apoptosis and cell cycle of peripheral blood lymphocytes, and immunologic function in vivo; and it was revealed that exposure to low level of sevoflurane has no significant harmful effects on peripheral blood lymphocytes of OR staff.

Nevertheless, there are some limitations in this study. First of all, all the subjects were limited to one hospital, and this environment may not be generalizable to other institutions. Secondly, there is a lack of long-term observation of the dynamic changes of the variables in the subjects. Multicenter and longterm follow-up studies with large samples are warranted to further confirm our results. Research about the effect of exposure to WAGs on cognitive function in addition to immune function is also worth investigation in the future.

\section{Conclusions}

In the modern laminar-flow OR, medical personnel's occupational exposure to sevoflurane does not exceed standard limits. Chronic occupational exposure to sevoflurane (less than limit of exposure) was found to have no significant harmful effect on the peripheral lymphocytes of OR staff.

\section{Acknowledgements \\ I would like to thank my colleagues from the Department of Anesthesiology and Internal Medicine of Puren Hospital for their support to this study.}

\section{Code availability}

flowjo software, ModFit LT software, SPSS software

\section{Authors' contributions}

Zhimin Ji and Li Li designed the whole study, performed all experiments and wrote the manuscript. Xinguo Wang and Cheng Zhang were responsible for measuring the concentration of sevoflurane. Wanjun Wu collected and organized data, and made statistical analysis and modified the manuscript. Qiuping Xu and Xueyong Peng were responsible for subject recruitment and information registration. Fan Zhou and Weibin Yang were responsible for apoptosis and cycle experiments. Wanjun Wu and Junfang Hu were responsible for analysis of lymphocyte subsets and immunoglobulin assay. The author(s) read and approved the final manuscript.

\section{Funding}

This study was financially supported by Hubei Province Key Laboratory of Occupational Hazard Identification and Control, Wuhan University of Science and Technology, 2018 Annual Open Fund (OHIC2018K02).

\section{Availability of data and materials}

The datasets used and analyzed during the current study are available from the corresponding author on reasonable request.

\section{Declarations}

Ethics approval and consent to participate

This study was approved by the Human Medical Research Ethics Review Board, Puren Hospital (prll2018001) prior to its initiation. All of the procedures were performed in accordance with the Declaration of Helsinki and relevant policies in China. All subjects who participated in this study provided written informed consent.

Consent for publication

Not applicable.

Competing interests

The authors declare that they have no competing interests. 


\section{Author details}

'Department of Anesthesiology, Puren Hospital Affiliated to Wuhan University of Science and Technology, Wuhan, China. ${ }^{2}$ Department of Anesthesiology, the Affiliated Suzhou Science and Technology Town Hospital of Nanjing Medical University, Suzhou, China. ${ }^{3}$ Department of Clinical Laboratory, Puren Hospital, Affiliated to Wuhan University of Science and Technology, Wuhan, China. ${ }^{4}$ Department of Pharmacy, Puren Hospital, Affiliated to Wuhan University of Science and Technology, Wuhan, China. ${ }^{5}$ Wuhan Municipal Health Commission, Wuhan, China. ${ }^{6}$ Department of Occupational Health, Wuhan Prevention and Treatment Center for Occupational Disease, Wuhan, China. ${ }^{7}$ Department of Pathology, Puren Hospital Affiliated to Wuhan University of Science and Technology, Wuhan, China.

Received: 1 January 2021 Accepted: 28 February 2021

Published online: 20 March 2021

\section{References}

1. Souza KM, Braz LG, Nogueira FR, Souza MB, Bincoleto LF, Aun AG et al, et al. Occupational exposure to anesthetics leads to genomic instability, cytotoxicity and proliferative changes. Mutation Res. 2016;791-792.

2. Deng HB, Li FX, Cai YH, Xu SY, et al. Waste anesthetic gas exposure and strategies for solution. J Anesth. 2018;32:2.

3. Vodicka P, Musak L, Fiorito G, Vymetalkova V, Vodickova L, Naccarati A, et al. DNA and chromosomal damage in medical workers exposed to anaesthetic gases assessed by the lymphocyte cytokinesis-block micronucleus (CBMN) assay. A critical review. Mutation Res. 2016;770:26-34.

4. Lucio LMC, Braz MG, do Nascimento Junior P, Braz JRC, Braz LG, et al. [Occupational hazards, DNA damage, and oxidative stress on exposure to waste anesthetic gases]. Rev Bras Aanestesiol. 2018;68:1.

5. Kunze N, Weigel C, Vautz W, Schwerdtfeger K, Junger M, Quintel M et al, et al. Multi-capillary column-ion mobility spectrometry (MCC-IMS) as a new method for the quantification of occupational exposure to sevoflurane in anaesthesia workplaces: an observational feasibility study. J Occup Med Toxicol. 2015;10:1-9.

6. Braz MG, Souza KM, Lucio LMC, Di Renzo GCC, Feliciano LM, Marcondes JPC et al, et al. Detrimental effects detected in exfoliated buccal cells from anesthesiology medical residents occupationally exposed to inhalation anesthetics: An observational study. Mutation Res Genet Toxicol Environ Mutagen. 2018;832-833.

7. Ferstandig LL, et al. Trace concentrations of anesthetic gases: a critical review of their disease potential. Anesthes Anal. 1978;57:3.

8. Szyfter K, Stachecki I, Kostrzewska-Poczekaj M, Szaumkessel M, Szyfter-Harris J, Sobczynski P, et al. Exposure to volatile anaesthetics is not followed by a massive induction of single-strand DNA breaks in operation theatre personnel. J Appl Genet. 2016;57:3.

9. Amiri F, Neghab M, Shouroki FK, Yousefinejad S, Hassanzadeh J, et al.Early, Subclinical Hematological Changes Associated with Occupational Exposure to High Levels of Nitrous Oxide. Toxics. 2018;6:4.

10. Matsuoka H, Kurosawa S, Horinouchi T, Kato M, Hashimoto $Y$, et al.Inhalation anesthetics induce apoptosis in normal peripheral lymphocytes in vitro. Anesthesiology. 2001;95:6.

11. Loop T, Dovi-Akue D, Frick M, Roesslein M, Egger L, Humar M, et al. Volatile anesthetics induce caspase-dependent, mitochondria-mediated apoptosis in human T lymphocytes in vitro. Anesthesiology. 2005;102:6.

12. Aun AG, Golim MA, Nogueira FR, Souza KM, Arruda NM, Braz JRC et al, et al. Monitoring early cell damage in physicians who are occupationally exposed to inhalational anesthetics. Mutation Res. 2018;812.

13. National Institute of Occupational Safety and Health (NIOSH):NIOSH Pocket Guide to Chemical Hazards. Washington, DC, U.S.; 1994.

14. van Engeland M, Nieland $\amalg$, Ramaekers FC, Schutte $B$, Reutelingsperger CP, et al.Annexin $\mathrm{V}$-affinity assay: a review on an apoptosis detection system based on phosphatidylserine exposure. Cytometry. 1998;31:1.

15. Kim KH, Sederstrom JM, et al. Assaying Cell Cycle Status Using Flow Cytometry. Curr Prot Mol Biol. 2015;111.

16. Kotfis K, Biernawska J, Zegan-Baranska M, Zukowski M, et al. Peripheral Blood Lymphocyte Subsets (CD4+, CD8 + T Cells, NK Cells) in Patients with Cardiovascular and Neurological Complications after Carotid Endarterectomy. Int J Mol Sci. 2015;16:5.
17. Lubbers J, van Beers-Tas MH, Vosslamber S, Turk SA, de Ridder S, Mantel E, et al. Changes in peripheral blood lymphocyte subsets during arthritis development in arthralgia patients. Arthritis Res Ther. 2016;18:1.

18. Byhahn C, Heller K, Lischke V, Westphal K, et al. Surgeon's occupational exposure to nitrous oxide and sevoflurane during pediatric surgery. World J Surg. 2001;25:9.

\section{Publisher's Note}

Springer Nature remains neutral with regard to jurisdictional claims in published maps and institutional affiliations.
Ready to submit your research? Choose BMC and benefit from:

- fast, convenient online submission

- thorough peer review by experienced researchers in your field

- rapid publication on acceptance

- support for research data, including large and complex data types

- gold Open Access which fosters wider collaboration and increased citations

- maximum visibility for your research: over $100 \mathrm{M}$ website views per year

At BMC, research is always in progress.

Learn more biomedcentral.com/submissions 